\title{
Quality Characteristics of Black Olive Paste with Natural Flavors "Dried Basil and Tomatoes"
}

\author{
Eslam El-Attar, Naglaa El-Gazaar andSalwa El-Magoli
}

Food science Department, Faculty of Agriculture, Cairo University

\section{ABSTRACT}

ommercial pickled black olives were prepared into paste after pitting,

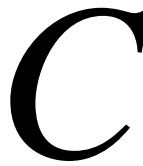
washing, grinding and natural flavors (Dried Basil and Tomatoes) were added each at $10 \%$ of paste. Flavored paste was filled in glass jars covered with olive oil and stored for 180days at room temperature. Olive paste samples were analyzed for physicochemical properties and sensory evaluation.PH values of the pastes were ranged 3.20 to 4.30.There were significant difference between olive paste without addition and olive paste with basil after 180days of storage, on other hand the olive paste with dried tomatoes had no significant difference after storage. HPLC results show differences of phenolic compounds between pastes. The processing and storage time increased the chromaticity coordinate $L^{*}, a^{*}$ and $b^{*}$ in the samples. Texture analysis showed significant difference only of olive paste with dried tomatoes.Sensory evaluation appeared some of differences of samples, the odor of olive paste with basil andappearance of olive paste with tomatoeshad a highly pleasant, but the olive paste without addition had ahighly pleasant of taste and overall acceptability.

Key words: Olive paste, Dried Basil, Sun-Dried tomatoes. 


\section{Introduction}

The olive fruit (Oleaeuropaea L.) was a small, thinnerfleshed drupe that is $1-2.5 \mathrm{~cm}$ long and grows on a small tree, which belongs to the family Oleaceae. It is native to tropical and warm temperate regions of the world (Aka et al, 2014). Olive was cultivated in various parts of the world and the Mediterranean region was accounted for $98 \%$ of global cultivation (Ryan et al, 1998). The consumption of freshly harvested olive fruit was not common due to the presence of Oleuropein and bitterness (Vinhaa et al., 2002). There were two ways for consumptions of olive fruit (Olea europaea), firstly named olive oil and secondary the table olives (Khan et al, 2015).

The Mediterranean diet appeared to be associated with a reduced risk of several chronic diseases including cancer and cardiovascular and Alzheimer's diseases. Olive products (mainly olive oil and table olives) were important components of the Mediterranean diet where Olives contained a range of phenolic compounds and these natural antioxidants might contribute to the prevention of these chronic diseases. Consequently, the consumption of table olives and olive oil continued to increase worldwide by health-conscious consumers (Charoenprasertand Mitchell, 2012).

Table olives are a complete food from a nutritional point of view. The energy value of $100 \mathrm{~g}$ of edible portion olives was around 200-250 kilocalories (Lanza, 2012). The protein content is low (1.0-2.2 g), but the nutritional quality is high because of the presence of essential amino acids (Young, 1994).

Table olives were a good source of dietary fibre, which in addition, had a high digestibility rate (López-López et al., 2007). The olive fruit was rich in phenolic compounds and there was a growing interest in this group due to their antioxidant activity and health benefits (Ryan et al., 2002). Olive pastes were very popular with consumers, particularly in Italy and France, 
and were used to spread on dry biscuits or bread as appetizers or as condiments for pasta, fish or meat dishes. They could be made from most olive varieties.

Pastes were prepared from processed green-ripe (green paste) to fully black-ripe olives (black paste) as reported by (Kailis and Harris,2007).

Tomatoes and tomato products are the major source of dietary lycopene; the health benefits of lycopene are attributed to its ability to protect cells against oxidative damage (Al-Shatwi,2010).

Basil has been planted as a popular culinary and medicinal herb from ancient time until now; it contains a wide range of phenolic compounds displaying various antioxidant activities (Pripdeevech et al, 2010).

The aim of this study was to develop new olive paste products using different natural flavors and study the quality characteristics during storage.
MATERIALS \&METHODS

Materials:

- Pickled olives were purchased from commercial company were pitted, washed and blended (the blending time depends on the granularity of olives).

- Three different types of pastes were prepared First mixture: olive paste without addition, second mixture: olive paste with dried basil (10/100g olive) and third mixture was olive paste with sun- dried tomatoes $(10 / 100 \mathrm{~g}$ olive $)$.

The prepared mixtures and samples were packed in glass jars and covered with $15 \mathrm{ml}$ of virgin olive oil. The pastes were pasteurized at Tunnel equipment $80^{\circ} \mathrm{c} / 10 \mathrm{~min}$ andstored at room temperature for 180 days.

\section{Methods}

\section{- Chemical analysis}

\section{PH Determination}

The $\mathrm{pH}$ was determined by apH meter (HANA instrument). 


\begin{abstract}
DPPH radical scavenging activity:

Antioxidant activity was determined by measuring the radical scavenging effect of methanolic extracts of the olives paste by using the 2, 2dipheny 1-1picrylhydracyl (DPPH) as reported by (Singh et al. 2002). Five milliliters of a $0.1 \mathrm{mM}$ methanol solution of DPPH were added to $0.1 \mathrm{~mL}$ of methanol extracts of samples of olive pastes inside glass tubes. The tubes were allowed to stand at $27{ }^{\circ} \mathrm{C}$ for 20 min. The decrease in absorbance at $517 \mathrm{~nm}$ was recorded using a spectrophotometerlaboratory instrument.

Radical scavenging
activity was expressed as
inhibition percentage and was
calculated using the following
formula: (Aromatic et al., 2013).
\end{abstract}

Inhibition $\%=($ [Acontrol $-\mathrm{A}$ sample $]$ /Acontrol $) \times 100$

where A control $=$ absorbance of the control reaction (containing all reagents except samples); A sample = absorbance of the test compound.

\section{Determination of Phenolic compounds}

Phenolic compounds of olive samples were determined by HPLC system according to the method of (Goupy et al., 1999) as follows: $5 \mathrm{~g}$ of each sample was mixed with methanol and centrifuged at $10000 \mathrm{rpm}$ for 10 min and the supernatant was filtered through $0.2 \mu \mathrm{m}$ Millipore membrane filter, 1-3 $\mathrm{ml}$ was then collected in a vial for injection into HPLC HewlletPackared (series 1050) equipped with auto sampling injector, and solvent degasser and Ultraviolet (UV) detector that set at $280 \mathrm{~nm}$ using quaternary HP pump (series 1100). The temperature of column wasmaintained at $35^{\circ} \mathrm{C}$.

\section{- Physical analysis}

\section{Color determination}

The color of the olive samples were measured by Chroma-meter(Konica Minolta CR 410, Japan). The colorimeter was calibrated against a standard calibration plate of a white surface and set to CIE Standard D65 Illuminant $\mathrm{C}$. The $\mathrm{L}^{*}, \mathrm{a}^{*}, \mathrm{~b}^{*}$ 
values were the averages of ten readings. The color brightness coordinate $\mathrm{L}^{*}$ measured the whiteness value of sample color (range from black at 0 to white at 100). The chromaticity coordinate $\mathrm{a}^{*}$ measured (red when positive and green when negative).

The chromaticity coordinate $b^{*}$ measured (yellow when positive and blue when negative) and $C^{*}$ was calculated as $(a * 2+b * 2) 1 / 2$ as reported by (Romero et al, 2002).

\section{Texture analysis}

The texture was carried out using the Sher Force (Universal Testing Machine).The distance travelled by the probe was with $37.55 \mathrm{~mm}$ diameter, the test speed was $60 \mathrm{~mm} / \mathrm{s}$ under room temperature as described by Bourne (1978).

\section{Sensory evaluation}

For Sensory evaluation the panel test was performed to obtain the degree of acceptance for 10 judges who evaluated the samples using criteria described by (Marsilio et al.,2008). The proof sheet contained a list of sensory descriptors (appearance, texture, odor, taste, and overall acceptability), A testing chart was used 5 points, [1] representing highly unpleasant and [5] representing highly pleasant was used.

\section{Statistical analysis}

Data were analyzed using IBM SPSS software package version

Significance of the obtained results was judged at the 5\% level. F-test ANOVA was used, Also Post Hoc test Tukey was used for pair wise comparisons (Kotz et al., 2006).

\section{Results\& Discussions}

PH value is an important parameter for technological and safety terms. According to the codex standard of table olive, the $\mathrm{PH}$ value of pasteurized black olives should be less than 4.3. In this study the initial $\mathrm{PH}$ value of natural black olives was 4.20 , after washing,blending and pasteurization the value decreased to 3.82 . 
$\mathrm{PH}$ values were ranged from 3.52 to 4.27 for all types during the 180 days of storage as shown in table (1). No significant difference was observed between the different treatments of black pastes.

Independently of the shelf life of the food product, consider to be safe if the $\mathrm{PH}$ does not exceed 4.5 , Food with $\mathrm{pH}$ values greater than 4.5 are prone to spoilage due to the growth of bacterial spores (Kailis and Harris, 2007). In the new olives products of this study olive paste without addition, olive paste containing $10 \%$ dried basil and olive paste containing $10 \%$ sun dried tomatoes the $\mathrm{PH}$ value was less than 4.3 which considered safe for human consumption.

Phenolic compounds are responsible for several important olive fruit characteristics: bitterness and browning. Their levels ranged from 1 to $3 \%$, of the weight of the fresh pulp (Garrido et al, 1997). The HPLC results in table (2) showed great differences between natural black olives and pastes. These changes could be due to the pasteurization process at $80^{\circ} \mathrm{C}$ in addition, sun dried tomato and basil may also affect the phenolic content.

The phenolic acids that predominate in olive fruit include caffeic acid, chlorogenic acids (ferulic, vanillic, and coumaric) were clearly identified by HPLC analysis (table 2), the results are in agreement with others (Pereira et al., 2006).

Pyrogallol content was reduced to $48 \%$, while the Oleuropein did not almost change in natural olive and olive paste without any addition. The Oleuropein range between 584.62$251.94 \mathrm{ppm}$ as shown in table (2), Oleuropein is generally the most prominent phenolic compound in olive cultivars and it is an ester consisting of hydroxytyrosol and elenolic acid (Charoenprasert and Mitchell, 2012).

The olive paste with basil had the highest amount of Vanillic acid, cinnamic and Ellagic acid (compared to the other types) this result was in agreement with (Javanmardi et al, 2002) who 
reported that the vanillic acid concentration of basil was in the range of $90-100 \mathrm{mg} / \mathrm{g}$. Ellagic acid is an important compound that exerts potent preventive and therapeutic effects against several types of cancers as mentioned by (Zhang, 2014).

The antiradical activity (DPPH \%) is used to maintain information on the radical scavenging activity. DPPH $\%$ of olive paste was from $79.75 \%$ to $59.13 \%$, as shown in table (3). All examined olive pastes showed antioxidant capacity, due to total phenolic contents and their antioxidant capacity seems to be widely influenced by the anthocyanin concentration in the pigmented black olives.

Compounds such as pyrogallol, Gallic acid and oleuropein have been reported to possess antioxidant properties as well as anti- inflammatory activities (Manpong et al. 2009 and Nicolis et al. 2008), these compounds had been observed in all three types of pastes (table 3 ).
The results show no significant differences between the different treatments in $\mathrm{DPPH} \%$ in zero time, but during storage(180 days) under room temperature, significant differences were found between samples due to storage except olive paste containg sun dried tomatoes. It decreases but the highest decreases were found in olive paste containing basil. Olive paste with sun-dried tomatoes shows the highest antioxidant activity, which confirms the findings of (ALShtawi et al , 2010) that tomatoes contain lycopene and vitamin (C) stable active antioxidants.

Table (4) showed the color parameters $L^{*}, a^{*}, b^{*}$ values. There were significant different between natural olives and olive pastes. $\mathrm{L}^{*}$ value in all samples revealed a low brightness, that is an indication of the presence of anthocyanin pigment which is responsible of dark color in the olive. The surface color became brighter due to pasteurization at $80^{\circ}$ C. The stability of anthocyanins and all pigments decreased with increases in 
temperature which is mainly the reason for bright. The values were significantly different from each other at 0 day of storage.

Color parameters had slightly increased after 180 days of storage that may be due to changes in anthocyanins(Mazza,1995)reporte $d$ that anthocyanin molecules areunstable and highly susceptible to degradation during storage. However the chromaticity coordinate $L^{*}, a^{*}$ and $b^{*}$ were increased in the three samples, and no significant differences were found.

Texture is an important attribute of food, largely determining its organoleptic quality (Peleg, 1987). Consumers products succeed in the marketplace in part because of their "textural characteristics" are pleasing customers (Aguilera and Stanley, 1999). However, texture integrates a set of mechanical, geometric and surface properties detectable by mechanical, tactile, visual and auditory receptors (Szczesniak, 2002).
Table (5) Shows results of olive paste types, hardness that defined as force required compressing a food between the molars, hardness value in the three types of black olive pastes were ranged between 2.15-2.45 N.S as shown in table (5).

Moreover, olives paste having sun- dried tomato showed maximal values of adhesiveness 0.70 N.S which defined as the maximum force required separating teeth after biting sample from other types .The consumer might or might not like the chewing of added dried tomatoes to the olive paste.

The cohesiveness was between 0.49 to 0.58 . On other hand these results are completely different from (Alvarenga et al , 2012) their results showed lower values of hardness ranging from 0.62 to 0.36 , adhesiveness from 1.63 to 2.66 and cohesiveness was higher than 1.27 , the results were due to the addition of a fatty substances. 
The sensory evaluation of black olive pastes are given in Figure1.The taste, odor,appearance, and overall acceptability attributes show significant differences between the samples, the appearance was between 4.32 to 3.86 , the taste was 4.84 in olive paste without addition , 4.5 in olive paste contains basil and 3.5 in olive paste with sun-dried tomatoes. The odor of the olive paste with basil was the best, which could be due to vanillic component.

\section{CONCLUSIONS}

There is a big market for olives not only in the Middle East but in Europe and other parts of the world, Consumers are more interested in pitted table olive either black or green whole olives because it's easier to use so introducing new flavors within easy to use paste could increase a market share of olive products.

Black olive paste with sun dried tomatoes and basil considered as a new products, that are; safe, nutritious, easy to use and can supply polyphenolic and antioxidant compounds which are important for human health.

\section{References:}

\author{
Aguilera JM and Stanley \\ DW(1999): \\ In:G.V.Barbosa-Cànovas \\ (Ed.),pp.185-249, \\ Microstructural Principles \\ of Food Processing and \\ Engineering, 2nd Ed., \\ Aspen PublishingCo., \\ Gaithersburg, MD.
}

Aka-

KayguluogluA;

AkpinarBayizit A and SahinCebeci $\quad$ O(2014):

Evaluation of physicochemical and sensory properties of green pastes .J. Traditional Knowledge. 13, 654-658.

Al-shatwi A; Al Obaaid M; Al Sedairy S; Al-Assaf A; Zhang $J$ and LeiK(2010): Tomato powder is more protective than lycopene supplement againstlipid peroxidation in rats. .J. science direct.30 .66-73. 
Alvarenga NB; Lidon FJ; Silva A; Martins G; Cruz T; Palma $\mathrm{V}$ and Canada $\mathrm{J}$ (2012):

Production and characterizationof green and black olive paste using cream of animal and vegetable origins.J. Food Agric. 24 (1): 12-16.

\section{AromaticFA; El-mhdwi MF;} Aromatic $F$ and Aromatic OO (2013):

Estimation of antioxidant activities of fixed and volatile oils extracted from Aromatic aromatic (clove). Pelagia Research Library .Der ChemicaSinica, 4(3):120-125.

\section{Charoenprasert S and Mitchell} A (2012):

Factors Influcing Phenolic Compounds in Table Olives (Olea-europaea).J. Agriculture and food chemistry.60, 7081-7095.

Garrido FA; Fernandez DMJ and Adams MR (1997):
Table Olives. Production and processing, Chapman \& Hall, London, UK.pp:90.

Goupy P; Hugues MBoivin P and Amiot MJ (1999):

Antioxidant Composition and Activity of Barley (Hordeum vulgare) and Malt Extracts and of Isolated Phenolic Compounds.Journal of the Science of Food and Agriculture, 79, 16251634.

Javanmardi J; Khalighi A; Kashi A; Bais HP and Vivanco JM. (2002):

Chemicalcharacterizationo $\mathrm{f}$ basil (Ocimumbasilicum L.)found in local accessions and used in traditional medicines in Iran. J. Agr Agriculture. Food Chem. 50:58785883.

Kailis SG and Harris DJ (2007) a:

Producing table olives: Quality and 
Safety.Australia:Land links press.pp.188.

Kailis SG and Harris DJ (2007) b:

Producing table olives: Quality and Safety. Australia: Land links press.pp. 256-259.

Khan MN; Soherwardy $R$ and Sarwar A (2015): Nutritional assessment of olive fruit (Oleaeuropaea) available at local market.J.International Food Research . 22, 526531.

Kotz S; Balakrishnan N; Read CB and Vitasovic B (2006):

Encyclopedia of statistical sciences. 2nd ed. Hoboken, N.J.: Wiley-Interscience

\section{Lanza B(2012):}

Olive Germplasm - The Olive Cultivation, Table Olive and Olive Oil Industry in Italy.INTECH publisher's .pp:353.
López-López A; Jiménez-Araujo

A; García-García, $P$ and Garrido-Fernández A (2007).

Multivariate analysis for the evaluation of fiber, sugars, and organic acids in commercial presentations of table olives.J. Agriculture and Food Chemistry 55: 10803-10811.

Manpong P; Douglas S; Douglas PL; Pongamphai $S$ and Teppaitoon W (2009): Response surface methodology applied to the extraction of phenolic compounds from Jatropha curcas Linn.Leaves using supercritical $\mathrm{CO} 2$ with a methanol co-solvent.J. Food. Proc. Eng.15: 1-20.

Marsilio V; Russi F; Iannucci E and Sbatini $N$ (2008): Effects of alkali neutralization with $\mathrm{CO} 2$ on fermentation, chemical parameters and sensory characteristics n Spanishstyle green olives (Olea 
europaea L.),LWT-food

SciTechnol, $41 \quad$ (5)

796-802.

MazzaG (1995):

Anthocyanins in grapes and grape products.Crit

Rev Food SciNutr .35: 341-371.

Nicolis E; Lampronti I; Dechecchi MC; Borgatti M; Tamanini A; Bianchi N; Bezzerri V; Mancini I; Giri MG; Rizzotti P; Gambari $\mathbf{R}$ and Cabrini G (2008):

Pyrogallol, an active compound from the medicinal plant Emblica officinalis, regulates expression of proinflammatory genes in bronchial epithelial cells. Int. J. Immunopharmaco. 8:1672-1680.

\section{Peleg GM (1987):}

Physical measures of texture.In: H. R. Moskowitz, (Ed.) pp. 1-95, Food Texture Marcell Dekker, Inc., New York,USA.

\author{
Pereira JA; Pereira AP; \\ Ferreira IC; Valentao $P$ \\ and Andrade PB(2006): \\ Table olives from \\ Portugal: Phenolic \\ compounds, antioxidant \\ potential and antimicrobial \\ activity. J. Agriculture and \\ food chemistry, 54. 8425- \\ 8431.
}
Priddeevech P; Chumpolsri W; Suttiarporn $\mathbf{P}$ and Wongponchai S(2010): The chemical composition and antioxidant activities of basilfrom Thailand using retention indices and comprehensive two- dimensional gas chromatography.J.Serb. Chem. Soc. 75 (11) 1503- 1513

\section{Romero C; García P; Brenes M; García Aand Garrido A (2002):}

Phenolic compounds in natural black Spanish olive varieties. Eur.Food Res. Technol. 215, 489- 49. 
Ryan D;Antolovich M; Prenzler $P$; Robards $K$ and Lavee $S$ (2002):

Biotrans formations of phenolic compounds in Olea europaea L. Sci. Hort. 92, 147-176.

Ryan D and Robards K (1998): Phenolic compounds in olives. Analyst 123: 31R44R.

\section{Singh RP; Murthy KNC} andJayaprakasha GK (2002):

Studies on the antioxidant activity of pomegranate(Punicagranat um) peel and seed extracts using invitro models. $J$. Agric. Food Chem. 50, 8186.
JA; Oliveira MB; Seabra RM and Andrade PB (2002):

Phenolic profiles of Portuguese olive fruits (Oleaeuropaea L.). Influences of cultivar and geographical.

\section{Szczesniak A S (2002): \\ Texture is a sensory property. Food Qual. Pref. 13:215-225.}

Vinhaa A F; Ferreres F; Silva

BM; Valentao P;

Goncalves A; Pereira 
Table 1: Comparison between PH values of olive paste during storage at room temperature:

\begin{tabular}{|c|c|c|c|c|}
\hline \multirow{2}{*}{$\begin{array}{c}\text { Storage time } \\
\text { (Days) }\end{array}$} & \multirow{2}{*}{$\begin{array}{c}\text { Pickled } \\
\text { olive }\end{array}$} & \multicolumn{3}{|c|}{ PH } \\
\hline & & S1 & S2 & S3 \\
\hline O & $\begin{array}{c}4.20^{\mathrm{a}} \pm \\
0.11\end{array}$ & $\begin{array}{c}3.82^{\mathrm{a}} \pm \\
0.24\end{array}$ & $\begin{array}{c}4.04^{\mathrm{a}} \pm \\
0.19\end{array}$ & $\begin{array}{c}3.52^{\mathrm{a}} \pm \\
0.19\end{array}$ \\
\hline 45 & & $\begin{array}{c}4.03^{\mathrm{a}} \pm \\
0.36\end{array}$ & $\begin{array}{c}4.17^{\mathrm{a}} \pm \\
0.30\end{array}$ & $\begin{array}{c}3.76^{\mathrm{a}} \\
\pm 0.33\end{array}$ \\
\hline 90 & & $\begin{array}{c}4.27^{\mathrm{a}} \pm \\
0.20\end{array}$ & $\begin{array}{c}4.20^{\mathrm{a}} \pm \\
0.44\end{array}$ & $\begin{array}{c}3.90^{\mathrm{a}} \pm \\
0.37\end{array}$ \\
\hline 135 & & $\begin{array}{c}3.73^{a} \pm \\
0.46\end{array}$ & $\begin{array}{c}4.09^{\mathrm{a}} \pm \\
0.33\end{array}$ & $\begin{array}{c}3.81^{\mathrm{a}} \pm \\
0.27\end{array}$ \\
\hline 180 & & $\begin{array}{c}3.87^{\mathrm{a}} \pm \\
0.15\end{array}$ & $\begin{array}{c}3.97^{\mathrm{a}} \\
\pm 0.24\end{array}$ & $\begin{array}{c}3.83^{\mathrm{a}} \pm \\
0.38\end{array}$ \\
\hline
\end{tabular}

S1; black olive paste; S2: Black olive paste with 10\% dried basil; S3: Black olive paste with $10 \%$ sun-dried tomatoes. Data was expressed by using mean $\pm S D$. 
Table2: Phenolic compounds of the different samples

\begin{tabular}{|c|c|c|c|c|}
\hline $\begin{array}{c}\text { phenolic } \\
\text { compounds }\end{array}$ & Pickled olive & S1 & S2 & S3 \\
\hline Pyrogallol & 1137.61 & 552.57 & 104.96 & 75.45 \\
\hline Protocatchuic & 151.29 & 60.62 & 17.65 & 16.4 \\
\hline catechein & 632.04 & 195.26 & 121.96 & 36.64 \\
\hline chlorogenic & 101.85 & 116.61 & 154.75 & 219.5 \\
\hline catechol & 325.59 & 159.5 & 69.71 & 78.36 \\
\hline caffeine & 79.53 & 51.72 & 14.52 & 9.72 \\
\hline Caffeic & 42.96 & 32.72 & 27.3 & 19.7 \\
\hline Vanillic & 58.87 & 26.17 & 104.91 & 30.32 \\
\hline P-coumaric & 57.61 & 15.79 & 10.09 & 6.3 \\
\hline Ferulic & 92.07 & 78.98 & 57.76 & 36.11 \\
\hline Iso-Ferulic & 7.26 & 8.28 & 21.17 & 12.42 \\
\hline Oleuropin & 584.62 & 550.05 & 423.52 & 251.94 \\
\hline Ellagic & 99.95 & 68.77 & 205.87 & 151.06 \\
\hline Coumarin & 28.21 & 33.14 & 14.94 & $\mathrm{ND}$ \\
\hline Salycilic & 128.84 & 66.25 & $\mathrm{ND}$ & $\mathrm{ND}$ \\
\hline Cinnamic & 3.95 & 6.51 & 12.28 & 2.53 \\
\hline
\end{tabular}

S1; black olive paste; S2: Black olive paste with 10\% dried basil; S3: Black olive paste with $10 \%$ sun-dried tomatoes. ND: Not detected 
Table 3: Radical scavenging activity of olive paste during storage at room temperature

\begin{tabular}{|c|c|c|c|c|}
\hline \multirow{2}{*}{$\begin{array}{c}\text { Storage time } \\
\text { (Days) }\end{array}$} & & \multicolumn{3}{|c|}{ DРPH\% } \\
\hline & $\begin{array}{l}\text { Pickled } \\
\text { olive }\end{array}$ & S1 & S2 & S3 \\
\hline $\mathbf{0}$ & $\begin{array}{l}84.37^{\mathrm{a}} \\
\pm 13.06\end{array}$ & $\begin{array}{c}79.75^{\mathrm{a}} \pm \\
10.62\end{array}$ & $\begin{array}{l}74.22^{\mathrm{a}} \\
\pm 8.79\end{array}$ & $\begin{array}{l}72.20^{\mathrm{a}} \\
\pm 8.20\end{array}$ \\
\hline 45 & - & $\begin{array}{l}57.40^{\mathrm{b}} \\
\pm 3.69\end{array}$ & $\begin{array}{c}58.96^{\mathrm{b}} \pm \\
4.57\end{array}$ & $\begin{array}{c}57.94^{\mathrm{b}} \pm \\
3.26\end{array}$ \\
\hline 90 & & $\begin{array}{c}55.41^{\mathrm{b}} \pm \\
2.12\end{array}$ & $\begin{array}{l}61.94^{\mathrm{ab}} \\
\pm 4.07\end{array}$ & $\begin{array}{c}59.91^{\mathrm{ab}} \\
\pm 3.54\end{array}$ \\
\hline 135 & & $\begin{array}{l}51.33^{\mathrm{b}} \\
\pm 3.53\end{array}$ & $\begin{array}{c}50.36^{\mathrm{b}} \pm \\
3.83\end{array}$ & $\begin{array}{c}49.33^{\mathrm{b}} \pm \\
2.73\end{array}$ \\
\hline 180 & & $\begin{array}{c}59.13^{\mathrm{b}} \pm \\
4.29\end{array}$ & $\begin{array}{c}53.26^{\mathrm{b}} \pm \\
1.68\end{array}$ & $\begin{array}{c}60.19^{\mathrm{ab}} \pm \\
3.53\end{array}$ \\
\hline
\end{tabular}

DPPH value: Inhibition $\%=($ [A control - A sample] $/$ A control $) \times 100$

S1; black olive paste; S2: Black olive paste with 10\% dried basil; S3: Black olive paste with $10 \%$ sun-dried tomatoes. Data was expressed by using mean $\pm S D$. 
Quality Characteristics of Black Olive Paste with Natural Flavors; Sun-Dried Basil and Dried Tomatoes

Eslam El-Attar, Naglaa El-Gazaar andSalwa El-Magoli

Table 4: Color parameters of olive paste before and after storage 180 days at room temperature

\begin{tabular}{|c|c|c|c|c|}
\hline Color & Pickled olive & S1 & S2 & S3 \\
\hline Initial & & & & \\
\hline L* $^{*}$ & $23.86^{\mathrm{c}} \pm$ & $30.02^{\mathrm{b}} \pm$ & $30.02^{\mathrm{b}} \pm$ & $31.34^{\mathrm{a}} \pm$ \\
& 0.04 & 0.15 & 0.15 & 0.45 \\
\hline $\mathbf{a}^{*}$ & $9.92^{\mathrm{b}} \pm$ & $10.94^{\mathrm{a}} \pm$ & $10.94^{\mathrm{a}} \pm$ & $6.15^{\mathrm{c}}$ \\
& 0.15 & 0.09 & 0.09 & \pm 0.05 \\
\hline $\mathbf{b}^{*}$ & $-0.15^{\mathrm{b}}$ & $-0.19^{\mathrm{b}}$ & $-0.19^{\mathrm{b}} \pm$ & $1.62^{\mathrm{a}} \pm$ \\
& \pm 0.06 & \pm 0.0 & 0.0 & 0.0 \\
\hline $\mathbf{C}$ & $9.92^{\mathrm{a}}$ & $10.63^{\mathrm{a}} \pm$ & $10.63^{\mathrm{a}} \pm$ & $6.36^{\mathrm{b}} \pm$ \\
& \pm 0.15 & 0.48 & 0.48 & 0.04 \\
\hline Final & & & & \\
\hline $\mathbf{L}^{*}$ & - & $32.25^{\mathrm{a}}$ & $32.25^{\mathrm{a}} \pm$ & $32.03^{\mathrm{a}} \pm$ \\
& & \pm 0.70 & 0.70 & $0.27^{\mathrm{a}}$ \\
\hline $\mathbf{a}^{*}$ & - & $11.86^{\mathrm{a}} \pm$ & $11.86^{\mathrm{a}} \pm$ & $11.87^{\mathrm{a}} \pm$ \\
& & $2.46^{\mathrm{a}}$ & 2.46 & 2.40 \\
\hline $\mathbf{b}^{*}$ & - & $4.08^{\mathrm{a}} \pm$ & $4.08^{\mathrm{a}} \pm$ & $4.05^{\mathrm{a}} \pm$ \\
& & 2.20 & 2.20 & $2.16^{\mathrm{a}}$ \\
\hline C & - & $12.66^{\mathrm{a}} \pm$ & $12.66^{\mathrm{a}} \pm$ & $12.64^{\mathrm{a}} \pm$ \\
& & 2.54 & 2.54 & 2.45 \\
\hline
\end{tabular}

S1; black olive paste; S2: Black olive paste with 10\% dried basil; S3: Blackolive paste with $10 \%$ sun-dried tomatoes. Data was expressed by using mean \pm SD. 
Table 5: Texture values of olive pastes at 0 day of storage

\begin{tabular}{|c|c|c|c|}
\hline \multirow{2}{*}{} & \multicolumn{3}{|c|}{ Texture } \\
\cline { 2 - 4 } & S1 & S2 & S3 \\
\hline Hardness & $2.15^{\mathrm{a}}$ & $2.20^{\mathrm{a}} \pm$ & $2.45^{\mathrm{a}} \pm$ \\
(N.S) & \pm 0.63 & 0.30 & 0.18 \\
\hline Adhesive force & $-1.0^{\mathrm{b}}$ & $-0.80^{\mathrm{b}} \pm$ & $0.70^{\mathrm{a}} \pm$ \\
(N.S) & \pm 0.26 & 0.26 & 0.11 \\
\hline Cohesiveness & $0.50^{\mathrm{a}} \pm$ & $0.58^{\mathrm{a}} \pm$ & $0.49^{\mathrm{a}} \pm$ \\
(Ratio) & 0.10 & 0.14 & 0.15 \\
\hline
\end{tabular}

S1; black olive paste; S2: Black olive paste with 10\% dried basil; S3: Black olive paste with $10 \%$ sun-dried tomatoes. Data was expressed by using mean $\pm S D$. 
Quality Characteristics of Black Olive Paste with Natural Flavors; Sun-Dried Basil and Dried Tomatoes

Eslam El-Attar, Naglaa El-Gazaar andSalwa El-Magoli

Figure 1: Sensory evaluation of different black olive pastes

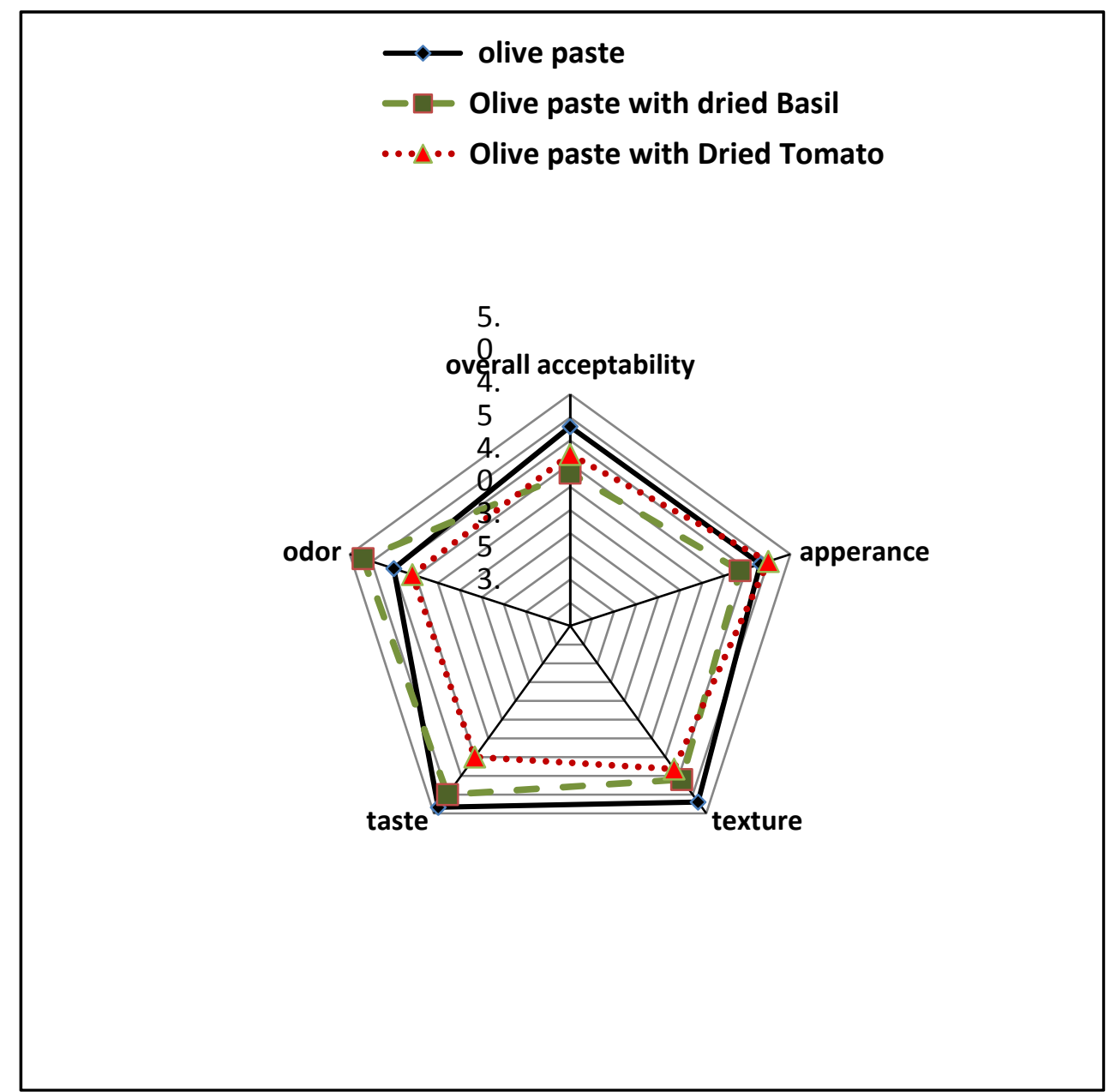

A testing chart using 5 points; where being 5 indicates, 1 indicates highly unpleasant and 5 highly pleasant, respectively.

Bulletin of the National Nutrition Institute of the Arab Republic of Egypt. June 2018 (51) 110 


\title{
خصائص الجودة لعجينة الزيتون الأسود المخلوطة

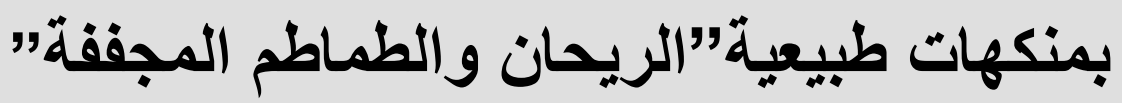

\author{
إسلام العطار،نجلاء الجزار و سلوي المجولي \\ قسم علوم الأغذية ،كلية الزراعة، جامعة القاهرة.
}

تم تحضير معجون الزيتون الأسود من الزيتون المخلل الطبيعى والذى تم تحضيرة داخل

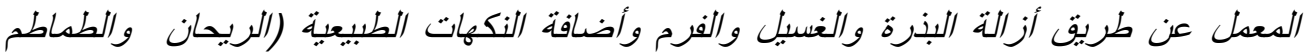

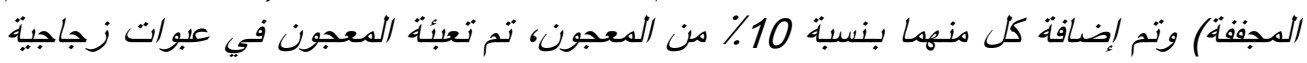

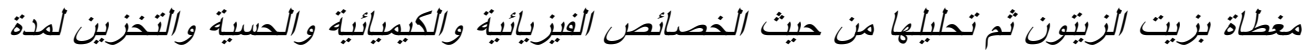

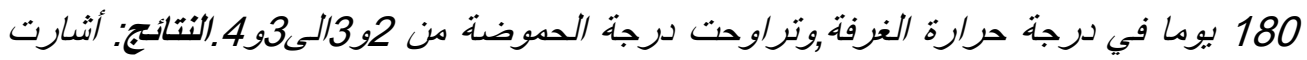

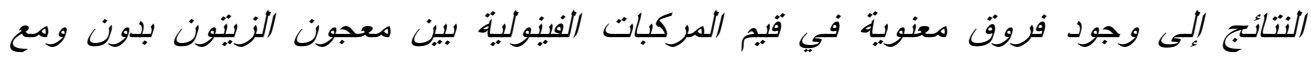

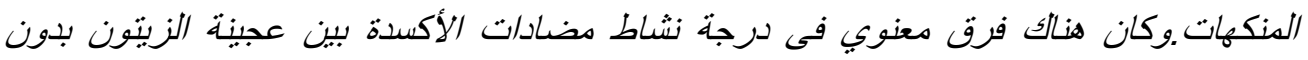

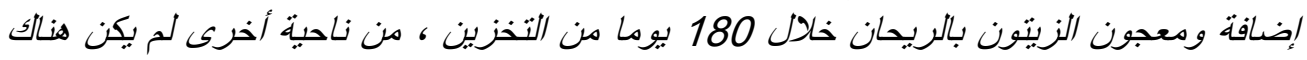

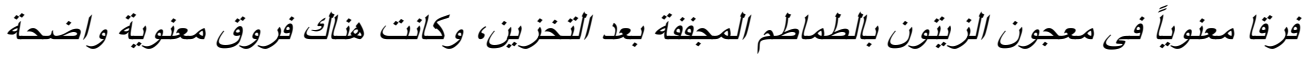
فى محتوى اللون و القوام والتقبيم الحسى بين العينات الثعاط الثلاث. الكلمات الدفتاحية :معجون الزيتون الأسود ـ الريحان الجاف ـ الطماطم الدجفةً 